\title{
$K_{\text {ATP }}$ Channels Are Involved in Regulatory Volume Decrease in Rat Cardiac Myocytes
}

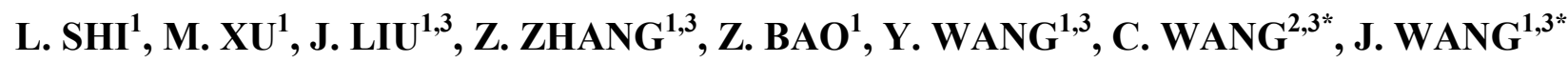 \\ "Authors contributed equally \\ ${ }^{1}$ Department of Physiology, School of Basic Medical Sciences, Capital Medical University, Beijing \\ $100069,{ }^{2}$ Beijing Chao-Yang Hospital, Beijing Institute of Respiratory Medicine, Capital Medical \\ University, Beijing 100020, ${ }^{3}$ Department of Respiratory Medicine, Capital Medical University, \\ Beijing 100069, PR China
}

Received May 6, 2008

Accepted August 27, 2008

On-line November 4, 2008

\section{Summary}

Regulatory volume decrease (RVD) is essential for the survival of animal cells. The aim of this study was to observe the RVD process in rat ventricular myocytes, and to determine if the $\mathrm{K}_{\mathrm{ATP}}$ channels are involved in the RVD process in these cells. By using reverse transcriptase polymerase chain reaction and Western blot analysis, we demonstrated that there are two types of $K_{A T P}$ channels expressed in rat ventricular myocytes: Kir6.1 and Kir6.2. When rat cardiac myocytes were exposed to hypotonic solution, cell volume increased significantly within $15 \mathrm{~min}$ and then gradually recovered. This typical RVD process could be inhibited by a $\mathrm{Cl}^{-}$channel blocker $(0.5 \mathrm{mM}$ 9-anthracene-carboxylic acid, 9-AC), a $\mathrm{K}^{+}$channel blocker $(5.0 \mathrm{mM} \mathrm{CsCl})$ and a $\mathrm{K}_{\mathrm{ATP}}$ channel blocker glibenclamide $(10 \mu \mathrm{M})$. Electrophysiological results showed that hypotonic solution activated a whole-cell current, which had similar biophysical characteristics with $\mathrm{K}_{\text {ATP }}$ opener (pinacidil)-induced currents. This current could be blocked by glibenclamide. Our data suggested that the RVD process in rat ventricular myocytes is dependent on the activation of $\mathrm{K}^{+}$ channels, and that $\mathrm{K}_{\mathrm{ATP}}$ channels are involved in this process.

\section{Key words}

Whole-cell patch clamp • ATP-sensitive $\mathrm{K}^{+}$channel • Regulatory volume decrease

\section{Corresponding author}

Jun Wang, M.D., Ph.D., Department of Physiology, School of Basic Medical Sciences, Department of Respiratory Medicine, Capital Medical University, Beijing 100069, P.R. China. Fax: 86-10-83911470(603). E-mail: wangjunbw@tom.com

\section{Introduction}

After hypoosmotic cell swelling, regulatory volume decrease (RVD) occurs due to efflux of $\mathrm{K}^{+}, \mathrm{Cl}^{-}$ and organic osmolytes, accompanied by osmotically obliged water loss (Hoffmann and Dunham 1995). RVD is an essential function for animal cells because osmotic perturbation is coupled to various physiological and pathological processes (e.g. proliferation, differentiation and programmed cell death) (Lang et al. 1998, Okada et al. 2001). In cardiac myocytes, cell swelling occurs during acute myocardial ischemia (Tranum-Jensen et al. 1981) and is exacerbated after reperfusion (Jennings et al. 1985). During the ischemic period, there is an intracellular accumulation of metabolites (e.g. lactate), which leads to an increase in cellular osmolality (Tranum-Jensen et al. 1981). Hence, water enters the cells, increases the cell volume, and alters the function of ion channel. Excessive changes in cell volume in the heart may cause profound alteration of structural integrity and constancy of the intracellular milieu, which affects many cellular functions and causes cell death. Reduction of cardiomyocyte swelling during myocardial ischemia by enhancing the regulation of cell volume may be a potential mechanism of cardioprotection.

Osmotic cell swelling has been reported to be associated with the activation of different ion channels, including $\mathrm{Cl}^{-}$and $\mathrm{K}^{+}$channels. The biophysical characteristics of the volume-sensitive $\mathrm{Cl}^{-}$channel that is relatively constant in different cell types, including 
cardiac myocytes, (Wang et al. 2005, Wang et al. 2006) has been described by ourselves and other research groups (Okada et al. 2001). The $\mathrm{K}^{+}$channel that is responsible for the volume regulation of cardiac myocytes has not been investigated intensively.

The volume-sensitive $\mathrm{K}^{+}$channel may have different molecular identification in different cell types. We have demonstrated that $\mathrm{Ca}^{2+}$-activated intermediate conductance $\mathrm{K}^{+}$channels are involved in the RVD process in human intestine 407 cells (Wang et al. 2003). In cardiac myocytes, the modulation effect of mechanical stretch on $\mathrm{K}_{\mathrm{ATP}}$ channel had been reported in atrial myocytes (van Wagoner 1993). It is well known that myocardial $\mathrm{K}_{\text {ATP }}$ channels play the key role in myocardial protective effect via ischemic preconditioning (IPC). Whereas, in rabbit ventricular myocytes, it was suggested that enhanced cell volume regulation was a key protective mechanism of IPC (Diaz et al. 2003). Thus, it is reasonable the postulate that $\mathrm{K}_{\mathrm{ATP}}$ channels may be a molecular entity that link IPC protection process and cell volume regulation. But till now, the information regarding the function of $\mathrm{K}_{\mathrm{ATP}}$ channels in the RVD process in rat cardiac myocytes is basically unavailable. In the present study, we sought to determine the role of $\mathrm{K}_{\mathrm{ATP}}$ channels in RVD process in rat ventricular cardiac myocytes.

\section{Materials and Methods}

Isolation of single cardiac myocytes

Adult female Sprague-Dawley rats (250-300 g) from the Experimental Animal Center of Capital Medical University (Beijing, China) were treated in accordance with the Guide for the Care and Use of Laboratory Animals issued by the National Committee of Science and Technology of China (1988) and approved by the State Council of China (1988). Isolation of single cardiac myocytes involved a previously described, wellestablished method (Wang et al. 2005, Wang et al. 2006). Briefly, rats were anesthetized by injection of sodium phenobarbitone $(50 \mathrm{mg} / \mathrm{kg}$, i.p.). Hearts were excised, arrested in ice-cold normal Tyrode solution and perfused using a Langendorff apparatus with normal Tyrode solution for $1 \mathrm{~min}$, and $\mathrm{Ca}^{2+}$-free Tyrode solution for another $7 \mathrm{~min}$. Then the perfusate was changed to $\mathrm{Ca}^{2+}$-free Tyrode solution containing collagenase type II $(1 \mathrm{mg} / \mathrm{ml}$, Worthington, USA) and BSA $(1 \mathrm{mg} / \mathrm{ml})$ for 20-25 min. All solutions were maintained at $37{ }^{\circ} \mathrm{C}$ and equilibrated with $95 \% \mathrm{O}_{2}-5 \% \mathrm{CO}_{2}$. The ventricles were cut off and minced to disperse the cells, stored at $4{ }^{\circ} \mathrm{C}$ in $\mathrm{KB}$ solution, used for further experiments (patch clamp and volume measurement) within $6 \mathrm{~h}$ of harvesting, and only quiescent cells with regular striations and no evidence of membrane bleb were selected for study.

Reverse transcriptase polymerase chain reaction (RT-PCR)

Total RNA was isolated from cardiac mycyotes by using TRIzol reagent (Sigma, USA) according to the manufacturer's instructions. The quality of the RNA was determined from the ratio of absorbance at $260 \mathrm{~nm}$ to that at $280 \mathrm{~nm}$. RNA was reverse-transcribed to synthesize first-strand cDNA and PCR was done by using an RNA PCR Kit (TaKaRa, Dalian, China). The specific primers were designed from coding regions of human Kir6.1 (forward primer: 5'-CCGTCTGTGTGACCAATGTC-3', reverse primer: 5'-CTGGTGAATAGGCACCACTC-3') and Kir6.2 (forward primer: 5'-GAAAGGGGGACAA GAAGGAG-3', reverse primer: 5'-ATGGTCCCCCAGA CAAAGTG-3'). As control for RNA integrity, the primer of glyceraldehyde phosphate dehydrogenase (GAPDH) was used (forward primer: 5'-ACCACAGTCCATGCCA TCAC-3' and reverse primer: 5'-TCCACCACCCTGTTG CTGTA-3'). PCR was done with an Icycler Thermal Cycler (Bio-Rad, Hercules, CA, USA) under the following conditions: the PCR reaction mixture was subjected to 30 cycles of denaturation at $94{ }^{\circ} \mathrm{C}$ for $0.5 \mathrm{~min}$, annealing at $55^{\circ} \mathrm{C}$ for $0.5 \mathrm{~min}$ and extension at $72{ }^{\circ} \mathrm{C}$ for $0.5 \mathrm{~min}$. This was followed by a final extension at $72{ }^{\circ} \mathrm{C}$ for $10 \mathrm{~min}$ to ensure complete product extension. Amplified products were separated by $1.5 \%$ agarose gel electrophoresis and stained with ethidium bromide. PCR product bands were visualized by UV light and sequenced with the ABI PRISM Big Dye Terminator Cycle Sequencing Ready Reaction kit and an ABI PRISM 310 genetic analyzer (Applied Biosystems, CA, USA).

\section{Western blot analysis}

The cardiac myocytes were harvested and lysed in Eukaryotic Cell Lysis Buffer (BioDev-Tech. Beijing, China) following the manufacturer's instructions. Protein $(100 \mu \mathrm{g})$ was mixed and boiled in SDS-PAGE sample buffer for $5 \mathrm{~min}$, separated by SDS-PAGE (12\% polyacrylamide gel) and then electro-transferred onto a nitrocellulose membranes by electroblotting in a Mini Trans-Blot. The transferred membrane was washed for 10 min with TTBS buffer containing (in $\mathrm{mM}$ ): 10 Tris- 
$\mathrm{HCl}, \mathrm{pH} \mathrm{7.4,} 150 \mathrm{NaCl}$, and $0.05 \%$ (w/v) Tween-20, followed by the blocking solution with $5 \%$ nonfat milk in TTBS for $1 \mathrm{~h}$. The blocked membrane was incubated with primary purified goat polyclonal antibody against Kir6.1 and Kir6.2 (Santa Cruz Biotechnology, CA, USA) at a 1:2000 dilution for $3 \mathrm{~h}$ at room temperature. For the second antibody, Fluorescently labeled secondary antibodies (IRDye 680 donkey anti-rabbit $\mathrm{IgG}$ ) were diluted in TTBS buffer and incubated for $1 \mathrm{~h}$ at room temperature. Membranes were scanned with Odyssey infrared imaging system at $680 \mathrm{~nm}$ and $780 \mathrm{~nm}$ wavelength (Li-COR, Biosciences, Lincoln, NE).

\section{Measurement of cell volume}

Measurement of cell volume was done as previously described (Diaz et al. 2003, Drewnowska and Baumgarten 1991, Wang et al. 2005). Briefly, a digital video-camera (Spot RF/SE; Diagnostic) mounted on an inverted microscope (Eclipse TE2000-U; Nikon) was used to acquire myocyte images $(400 \times$ magnification) at intervals of 1-5 min during the entire experimental protocol. Each image was used for computer tracing all myocyte edges to calculate myocyte area (NIH Image, version 1.62). Cell dimensions (diameter or width and length) were measured using two calibrated graticules (one for width and the other for length) in the microscope. Cell volume was estimated with assumed right cylindrical geometry according to the following equation: $\mathrm{V}=\pi \mathrm{L}(\mathrm{D} / 2)^{2}$ (where $\mathrm{V}, \mathrm{L}$ and $\mathrm{D}$ are cell volume, length and diameter, respectively) (Wang, et al. 2005). Using each cell as its own control, relative cell volume was calculated as follows:

$$
\mathrm{Vol}_{\mathrm{t}} / \mathrm{Vol}_{\mathrm{c}}=\pi\left(\mathrm{L}_{\mathrm{t}} \times\left(\mathrm{D}_{\mathrm{t}} / 2\right)^{2}\right) / \pi\left(\mathrm{L}_{\mathrm{c}} \times\left(\mathrm{D}_{\mathrm{c}} / 2\right)^{2}\right)
$$

where $\mathrm{t}$ and $\mathrm{c}$ refer to test (e.g. hypotonic solution) and control (isotonic solution) solutions respectively (Clemo et al. 1999). From these cell volume measurements, the RVD for each myocyte was calculated according to the following formula:

$\mathrm{RVD}=\frac{\% \text { cell volume at peak time }-\% \text { cell volume at } 40 \mathrm{~min}}{\% \text { cell volume at peak time }}$

During volume measurement, cells were first stabilized in isotonic solution for at least $10 \mathrm{~min}$, and then exposed to hypotonic solution for $30 \mathrm{~min}$, followed by $10 \mathrm{~min}$ of re-exposure to isotonic solution. Blockers were added 2-3 min before and during application of hypotonic solution.

Cell volume data are reported as a decimal fraction of baseline cell volume (e.g. an increase in cell volume of $13 \%$ is 1.13). RVD calculations are also reported as decimal fractions (e.g. 0.50) (Diaz et al. 2003). Experiments were carried out at room temperature.

\section{Electrophysiological measurements}

The tight-seal, whole-cell voltage-clamp technique was used as previously described (Wang et al. 2005, Wang et al. 2006, Wang et al. 2003). Pipettes were pulled from borosilicate glass capillaries with a micropipette puller (P-2000; Sutter Instruments, Novato, CA). The electrode had a resistance of 2.0-4.0 $\mathrm{M} \Omega$ when filled with pipette solution. Data were acquired using an EPC-10 amplifier and Pulse software (HEKA Electronics, Lambrecht, Germany). Current signals were low-pass filtered at 2.9 and $1.0 \mathrm{kHz}$ using a four-pole Bessel filter and digitized at $10 \mathrm{kHz}$. Sampled data were analyzed by an original software application called PatchMaster and Origin 7.0 (Origin Lab, Northampton, MA). In most experiments, a grounded $\mathrm{Ag}-\mathrm{AgCl}$ pellet electrode was placed in the perfusion solution. When $\mathrm{Cl}^{-}$-free bath solution was used, a $3.0 \mathrm{M}$ $\mathrm{KCl}$-agar bridge was employed. Series resistance was compensated $60-70 \%$ to minimize voltage errors. The time course of whole-cell current activation and recovery was monitored repetitively by applying (every $15 \mathrm{~s}$ ) ramp pulses (of duration $1 \mathrm{~s}$ ) from $-100 \mathrm{mV}$ to $+100 \mathrm{mV}$ from a holding potential of $-40 \mathrm{mV}$. Cell membrane capacitance was estimated from the integral of the transient current response to a $5 \mathrm{mV}$ hyperpolarizing clamp step, and all whole-cell currents were normalized to this value. To obtain whole cell I-V relations, step pulses were applied from a holding potential $-40 \mathrm{mV}$ to test potentials (1 s duration) of -100 to $+100 \mathrm{mV}$ (in $20 \mathrm{mV}$ increments). To minimize $\mathrm{Ca}^{2+}$ and/or swelling-activated $\mathrm{Cl}^{-}$currents, whole-cell recordings were carried out using low $-\mathrm{Cl}^{-}$intracellular solution and $\mathrm{Cl}^{-}$-free external solution containing a $\mathrm{Cl}^{-}$ channel blocker, 9-anthracenecarboxylic acid (9-AC).

\section{Solutions and chemicals}

Normal Tyrode solution for isolation of single cardiac myocytes contained the following (mM): 137.0 $\mathrm{NaCl}, 5.4 \mathrm{KCl}, 0.5 \mathrm{MgCl}_{2}, 1.8 \mathrm{CaCl}_{2}, 0.33 \mathrm{Na}_{2} \mathrm{HPO}_{4}$, 5.0 glucose, and 10.0 Hepes (pH 7.3 with $\mathrm{NaOH}$ ). $\mathrm{CaCl}_{2}$ was omitted from normal Tyrode solution to produce $\mathrm{Ca}^{2+}$-free Tyrode solution. $\mathrm{KB}$ solution comprised of (mM): $70.0 \mathrm{KOH}, 40.0 \mathrm{KCl}, 50.0$ L-glutamic acid, 
A

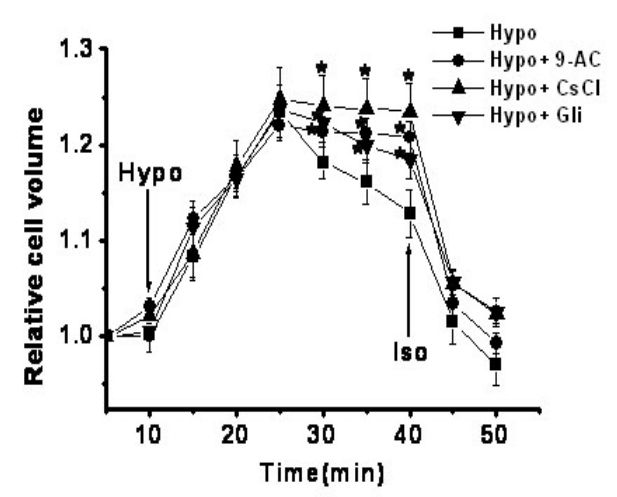

B

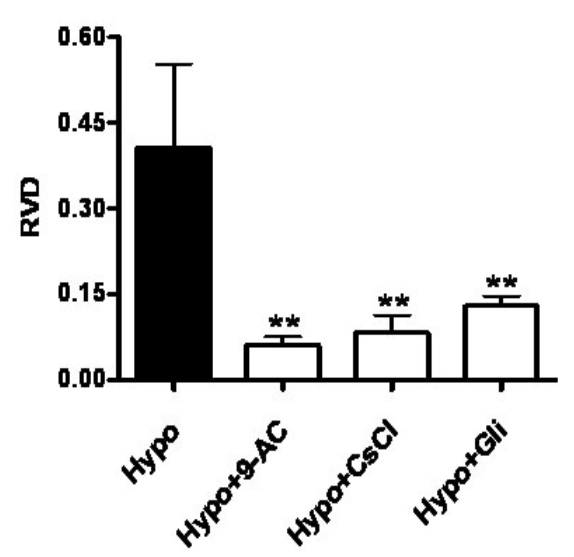

Fig. 1. Effect of $\mathrm{Cl}^{-}$channel and $\mathrm{K}^{+}$ channel blockers on cell volume regulation in rat ventricular myocytes. A. After $10 \mathrm{~min}$ in isotonic solution, cells were exposed to hypotonic solution for $30 \mathrm{~min}$, followed by $10 \mathrm{~min}$ of re-exposure to isotonic solution. Blockers were added 2-3 min before and during application of hypotonic solution. Each symbol represents the mean \pm SE (vertical bar) of 10 observations. $* P<0.01$ vs. hypotonic. B. Blockade effect of different blockers on the RVD capability. After $30 \mathrm{~min}$ exposure to the hypo-osmotic solution, RVD in hypotonic solution was $0.41 \pm 0.15$. Addition of 9-AC, $\mathrm{CsCl}$ and glibenclamide produced a significant reduction in RVD (hypo+9-AC: $0.06 \pm 0.01$; hypo+ CsCl: $0.08 \pm 0.03$; hypo+ glibenclamide: $0.13 \pm 0.02$ ) respectively. Data are expressed as mean \pm SEM. $* * P<0.01$ vs. hypotonic condition. $(n=10)$.
20.0 taurine, $0.5 \quad \mathrm{MgCl}_{2}, \quad 1.0 \quad \mathrm{~K}_{2} \mathrm{HPO}_{4}, \quad 0.5$ EGTA, 10.0 Hepes, 5.0 creatine, and 5.0 pyruvic acid $(\mathrm{pH} 7.38$ with $\mathrm{KOH})$. The isotonic $\left(\sim 312 \mathrm{mosmol} / \mathrm{kg} \mathrm{H}_{2} \mathrm{O}\right)$ or hypotonic $\left(\sim 212 \mathrm{mosmol} / \mathrm{kg} \mathrm{H}_{2} \mathrm{O}\right)$ solution used for cell volume measurement contained $(\mathrm{mM}): 5.4 \mathrm{KCl}$, $100.0 \mathrm{NaCl}, 1.0 \mathrm{MgCl}_{2}, 1.8 \mathrm{CaCl}_{2}, 100.0$ or 0 mannitol, and 10.0 Hepes ( $\mathrm{pH} 7.4$ with $\mathrm{NaOH}$ ). The pipette solution contained $(\mathrm{mM})$ : $140.0 \mathrm{~K}$-aspartate, $10.0 \mathrm{Na}$ aspartate, 1.0 $\mathrm{MgCl}_{2}$, 1.0 Mg-ATP, 2.0 EGTA, and 5.0 Hepes ( $\mathrm{pH} 7.3$ with $\mathrm{KOH})$. The $\mathrm{Cl}^{-}$-free isotonic $(\sim 310$ mosmol/ $\left.\mathrm{kg} \mathrm{H}_{2} \mathrm{O}\right)$ or hypotonic $\left(\sim 210 \mathrm{mosmol} / \mathrm{kg} \mathrm{H}_{2} \mathrm{O}\right)$ bath solution contained $(\mathrm{mM})$ : $5.4 \mathrm{~K}$-aspartate, 100.0 Na-aspartate, $1.0 \mathrm{MgSO}_{4}, \quad 1.8 \mathrm{CaSO}_{4}, 100.0$ or 0 mannitol, and 10.0 Hepes ( $\mathrm{pH} 7.4$ with $\mathrm{NaOH}$ ), as well as 0.5 9-AC. To test the $\mathrm{K}^{+}$selectivity of current, $\mathrm{K}^{+}$aspartate in the bath solution was replaced by equimolar of $\mathrm{Na}^{+}$-aspartate.

Reagents were obtained from Sigma-Aldrich Chemical Company (Shanghai, China). Stock solutions of 9-AC, pinacidil and glibenclamide were prepared in dimethyl sulfoxide (DMSO). The concentration of DMSO in the experimental solutions was $<0.1 \%$.

\section{Statistical analysis}

Data are presented as means \pm SE of $n$ observations. Statistical differences in data were evaluated by one-dimensional ANOVA and Scheffe's post-hoc multiple comparison tests. $\mathrm{P}<0.05$ was considered significant.

\section{Results}

KATP channels participated in the RVD process of rat cardiac myocytes

Figure 1A shows the time course of a typical volume response of single cardiac myocyte during hypoosmotic perfusion. Under isotonic condition $\left(\sim 312 \mathrm{mosmol} / \mathrm{kg} \mathrm{H}_{2} \mathrm{O}\right)$, the volume of cardiac myocytes remained stable throughout the entire perfusion period (data not shown). Upon exposure to hypotonic solution $\left(\sim 212 \mathrm{mosmol} / \mathrm{kg} \mathrm{H}_{2} \mathrm{O}\right)$, the mean volume of cardiac myocytes increased significantly $(123.45 \pm 2.72 \%$, $P<0.05$ versus isotonic condition) within $15 \mathrm{~min}$, and then gradually recovered as described previously in single chick cardiac myocytes (Hall et al. 1997). After restoration to isotonic solution, cell volume significantly decreased to the initial baseline within $10 \mathrm{~min}$. This result demonstrated that rat ventricular myocytes exhibited a typical RVD process, which was inhibited by application of $0.5 \mathrm{mM}$ 9-AC (a $\mathrm{Cl}^{-}$channel blocker), $5.0 \mathrm{mM} \mathrm{CsCl}$ (a $\mathrm{K}^{+}$channel blocker), or $10 \mu \mathrm{M}$ glibenclamide (which is known to be a specific blocker of $\mathrm{K}_{\mathrm{ATP}}$ channels at this concentration) 2-3 min before and during application of hypotonic solution. After a 30-min exposure to the hypoosmotic solution, RVD in control myocytes was $0.41 \pm 0.15$ (Fig. 1B). Whereas addition of 9-AC, $\mathrm{CsCl}$ and glibenclamide in hypotonic solution produced a significant reduction in RVD (hypo+9-AC: $0.06 \pm 0.01$; hypo+CsCl: $0.08 \pm 0.03$; hypo+glibenclamide: $0.13 \pm 0.02$ ), 
A

Iso

Iso+pina

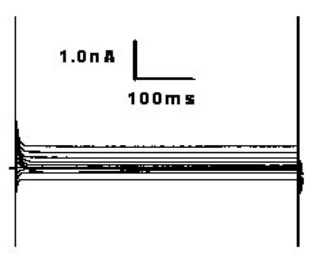

Iso+pina+Gli

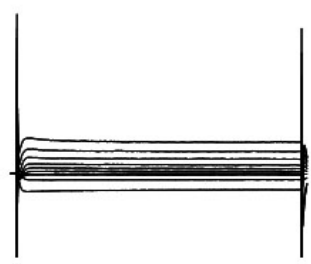

Fig. 2. Whole-cell $K_{\text {ATP }}$ currents activated by pinacidil in rat ventricular myocytes. A. The whole-cell currents elicited by a series of voltage steps from a holding potential of $-40 \mathrm{mV}$ to potentials between $-100 \mathrm{mV}$ and $+100 \mathrm{mV}$ in $20 \mathrm{mV}$ increments. B. I-V curve of the pinacidil activated currents with or without glibenclamide. Similar results were obtained from 5 cells.

B

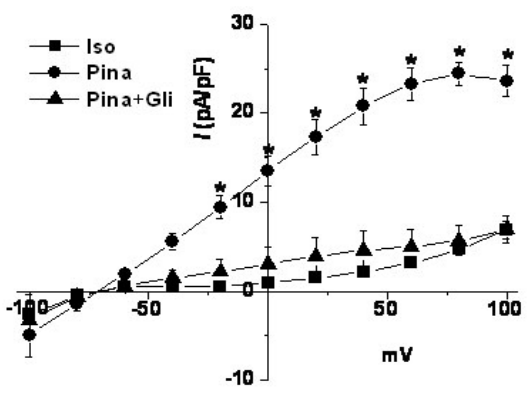

no significant difference in cell swelling was found between the hypotonic group with or without blockers. The increase in cell volume mainly resulted from a distinct increase in the radial dimensions of the cell in hypotonic solution with little or no change in longitudinal dimension, as previously reported (Vandenberg et al. 1996). In the light of these data, we conclude that $\mathrm{Cl}^{-}$ channels and $\mathrm{K}^{+}$channels are responsible for the RVD process of rat cardiac myocytes, and that $\mathrm{K}_{\mathrm{ATP}}$ channels are at least partially involved in this process.

The characteristics of $K_{A T P}$ currents in rat cardiac myocytes

The characteristics of $\mathrm{K}_{\mathrm{ATP}}$ currents in rat ventricular myocytes was observed by using a $K_{\text {ATP }}$ opener, pinacidil to induce the whole cell current. When cardiac myocytes were dialyzed with low- $\mathrm{Cl}^{-}$pipette solution and exposed to isotonic $\mathrm{Cl}^{-}$-free bath solution containing 9-AC (0.5 mM), voltage step from holding potential of $-40 \mathrm{mV}$ to potentials between $-100 \mathrm{mV}$ and $+100 \mathrm{mV}$ activated only a small current under control conditions. Whereas, application of pinacidil $(50 \mu \mathrm{M})$ in the bath solution resulted in a dramatic increase in the amplitude of the current. Subsequent application of glibenclamide $(10 \mu \mathrm{M})$ in addition to pinacidil reduced the current to nearly control levels (Fig. 2A). The reversal potential for the pinacidil-induced current $(-71.5 \mathrm{mV})$ is near the calculated equilibrium potential for $\mathrm{K}^{+}$ (-84.1 mV) (Fig. 2B).

\section{Cardiac myocyte swelling activated $K_{A T P}$ current}

We used whole cell patch clamp technique to record the hypotonic-activated $\mathrm{K}^{+}$current to demonstrate further that $\mathrm{K}_{\mathrm{ATP}}$ channel participated in the RVD process. A hypotonic challenge $\left(\sim 210\right.$ mosmol/ $\left./ \mathrm{kg} \mathrm{H}_{2} \mathrm{O}\right)$ reversibly induced an increase in cell membrane currents in single ventricular myocytes with low- $\mathrm{Cl}^{-}$pipette solution and $\mathrm{Cl}^{-}$-free bath solution containing $0.5 \mathrm{mM}$ 9-AC (Fig. 3). The profile of the swelling-induced current (Fig. 3A) and the $\mathrm{I}-\mathrm{V}$ relation (Fig. 3B) were similar to that of the pinacidil-induced current (Fig. 2). This current was also sensitive to $\mathrm{K}_{\mathrm{ATP}}$ channel blocker, glibenclamide (Fig. 3C). The reversal potential (Erev) for the hypotonic induced glibenclamide-sensitive current was $-60.2 \mathrm{mV}$, which is near to the Erev of $\mathrm{K}^{+}$. When extracellular $\mathrm{K}^{+}$ concentration $\left(\left[\mathrm{K}^{+}\right]_{\mathrm{o}}\right)$ was increased, the Erev shifted in the positive direction. The Erev shift per ten fold increase in $\left[\mathrm{K}^{+}\right]_{\mathrm{o}} /\left[\mathrm{K}^{+}\right]_{\mathrm{i}}$ was $43 \mathrm{mV}$, the linear equation $\left(\mathrm{E}=-42.89842 \log \left[\mathrm{K}^{+}\right]_{\mathrm{o}} /\left[\mathrm{K}^{+}\right]_{\mathrm{i}}+0.36831\right)$ comes from Figure $3 \mathrm{D}$, indicating the high selectivity of $\mathrm{K}^{+}$. These results suggested that $\mathrm{K}_{\text {ATP }}$ channels were activated by cell swelling.

Molecular expression of $K_{A T P}$ channels in rat ventricular myocytes

RT-PCR and western blot were carried out to examine the expression of the splice variants for Kir6.1 and Kir6.2 in rat ventricular myocytes. Specific primers were chosen on each side of the splicing site, thus amplifying two fragments of different sizes when both isoforms were expressed. As shown in Figure 4A (lanes 3 and 4), DNA fragments of expected size at 383 bp and 282 bp were amplified by Kir6.1 and Kir6.2 specific primers from reverse-transcribed cDNA. The nucleotide 
A

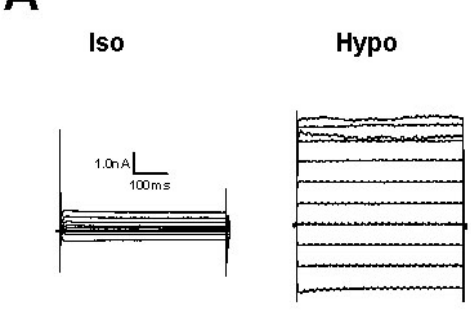

C

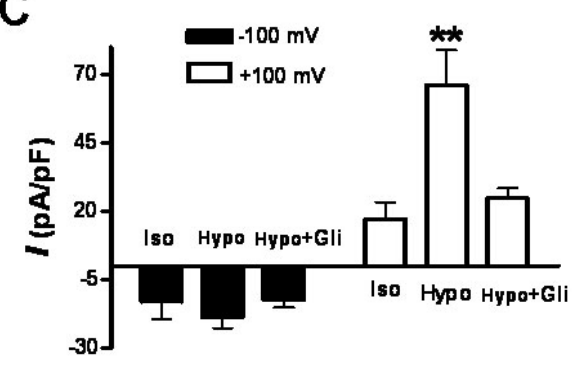

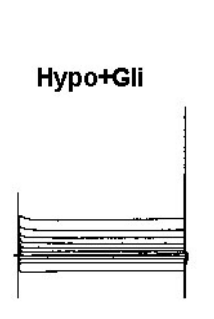

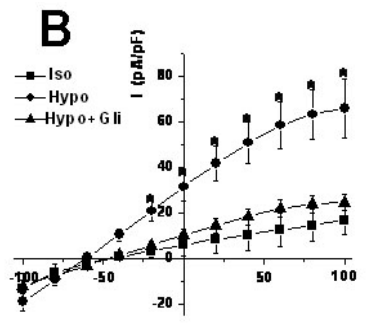

D

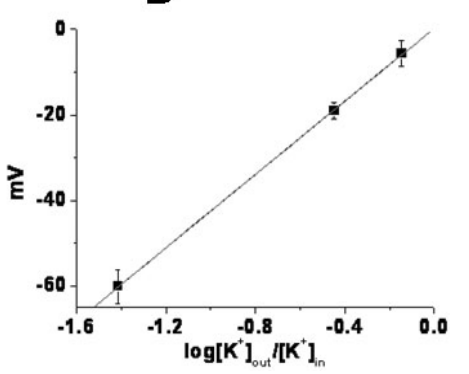

Fig. 3. Whole-cell currents activated by hypotonic solution in rat ventricular myocytes. A. The original traces obtained from whole-cell clamp in isotonic solution, in hypotonic solution and in hypotonic solution with glibenclamide (Hypo+Gli). B. I-V curves of hypotonic activated current with or without glibenclamide. C. Average data of the amplitude of the $\mathrm{K}_{\text {ATP }}$ currents evoked by hypotonic solution with or without glibenclamide, measured at $+100 \mathrm{mV}$ and $-100 \mathrm{mV}$, respectively $(\mathrm{n}=7) . \quad * * P<0.01 \quad v s$ isotonic and Gli group at $+100 \mathrm{mV}$. D. The fitting line of the reversal potential shift with different extracellular potassium concentrations $(n=8)$. sequence of these PCR products was identical to the corresponding sequence in the rat Kir channel. No PCR product was amplified when reverse transcriptase was omitted from the reaction (data not shown). Fig. 4B showed the protein expression of Kir6.1 and Kir6.2 in rat cardiac myocytes analyzed using western blot. The specific Kir6.1 and Kir6.2 bands were detected clearly at $51 \mathrm{kDa}$ and $40 \mathrm{kDa}$ respectively. These results consistent with the result of Wu et al. (2007).

\section{Discussion}

Volume regulatory mechanisms are essential to maintain the structural integrity and efficient functioning of cells. Various factors modify intra- or extracellular osmolarity and thus challenge the osmotic equilibrium across the cell membrane, and therefore cell volume. Defects in volume regulation of cardiac myocytes can occur as a result of metabolic imbalance during myocardial ischemia and reperfusion. Uncontrolled cardiac swelling leads to rupture of the sarcolemma and cell death.

A complex series of cellular control mechanisms have been shown to have roles in the control and regulation of cardiac cell volume under normal and adverse conditions. The most rapid and efficient means to accomplish cell volume regulation is ion transport across the cell membrane. The modulation of several $\mathrm{K}^{+}$selective channels by hypotonic condition in cardiac myocytes (including fast-inactivating voltage-dependent transient outward $\mathrm{K}^{+}$channel, rapid and slow components of delayed rectifier potassium current) has been reported from various preparations (Wang et al. 2005, Wehner et al. 2003, Rees et al. 1995, Sasaki et al. 1994).

The $\mathrm{K}_{\mathrm{ATP}}$ channel couples the metabolic state of the cardiac myocyte to its electrical activity. It was known to play an important part in IPC, which has been shown to ameliorate ischemia-induced cell swelling at the cellular and mitochondrial level. Cell swelling is an important cause of cell death induced by ischemia and reperfusion. Cell volume regulation has been suggested to be a key mechanism accounting for most of the IPC protection in cardiomyocytes in ventricular myocytes (Diaz et al. 2003). Enhanced cell volume regulation may be a key protective mechanism of ischemic preconditioning in rabbit ventricular myocytes (Diaz et al. 2003). IPC protection has a close relationship with cell volume regulation, but the molecular identity for the link is not clear.

Mechanical gating properties of the $\mathrm{K}_{\mathrm{ATP}}$ channel (van Wagoner 1993) have been reported. Hypotonic stress could enhance the slope conductivity of $\mathrm{K}_{\mathrm{ATP}}$ channels activated by $\mathrm{K}_{\mathrm{ATP}}$ openers (Kocic et al. 2007). In guinea-pig ventricular myocytes, prolonged myocardial ischemia has been shown to cause the duration of the ventricular action potential (AP) to decrease, (Priebe and Beuckelmann 1998), which protects the cell by decreasing calcium influx, thereby reducing inotropy and energy consumption. The possible mechanism underlying this shortening of AP duration is the activation of $\mathrm{K}_{\mathrm{ATP}}$ channels. The activation of $\mathrm{K}_{\mathrm{ATP}}$ in this situation can not be explained by the reduction in 
A

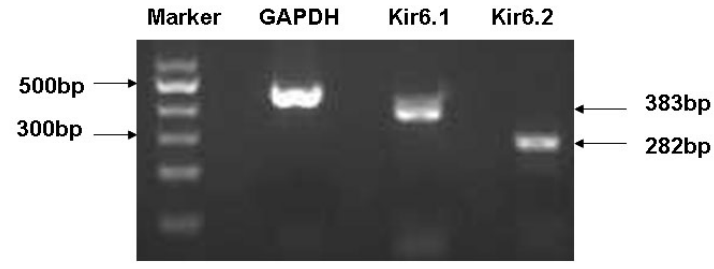

B

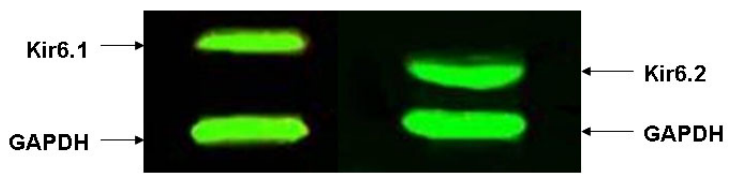

Fig. 4. Molecular expression of $K_{\text {ATP }}$ channel in rat cardiac myocytes. A. RT-PCR for Kir6.x mRNA in rat ventricular myocytes. Expected fragment sizes in the graph are as follows: Kir6.1, 383 bp (lane 3); Kir6.2, 282 bp (lane 4). B. Western blot results for Kir6.1 and Kir6.2. The specific Kir6.1 and Kir6.2 bands were detected clearly at $51 \mathrm{kDa}$ and $40 \mathrm{kDa}$ respectively.

ATP concentration in cardiac myocytes because AP duration decreases significantly when the ATP concentration is $>3 \mathrm{mM}$. Cell swelling could also shorten AP duration in guinea-pig ventricular myocytes by activating $\mathrm{K}_{\mathrm{ATP}}$ (Priebe and Beuckelmann 1998). This phenomenon could partially explain why $\mathrm{K}_{\mathrm{ATP}}$ channels appear to open during early ischemia, before ATP levels have decreased to the levels below which the channels can be activated in isolated patch experiments. But till now, there is no direct evidence to demonstrate that $\mathrm{K}_{\mathrm{ATP}}$ channels are involved in the RVD process in rat cardiac myocytes.

In the present experiments, the RVD process could be maximally blocked by $\mathrm{Cl}^{-}$channel blocker (9-AC) and $\mathrm{K}^{+}$channel blocker $(\mathrm{CsCl})$, demonstrating that the parallel activation of $\mathrm{Cl}^{-}$and $\mathrm{K}^{+}$channel was responsible for the RVD process. However, glibenclamide $(10 \mu \mathrm{M})$, a $\mathrm{K}_{\mathrm{ATP}}$ channel blocker, could also inhibit the RVD process. These results suggested the $\mathrm{K}_{\mathrm{ATP}}$ channels were involved in RVD in rat cardiac myocytes. Although glibenclamide has been reported to block the volume-sensitive $\mathrm{Cl}^{-}$channel, but at the concentration of $10 \mu \mathrm{M}$, it could only blocks the $\mathrm{K}_{\mathrm{ATP}}$ current without affecting the volume-sensitive $\mathrm{Cl}^{-}$ channel.

Our results provide the following evidences for $\mathrm{K}_{\mathrm{ATP}}$ channels in the rat heart: (i) there are two types of $\mathrm{K}_{\mathrm{ATP}}$ channels expressed in rat ventricular myocytes: Kir6.1 and Kir 6.2 and (ii) the pharmacological and electrophysiological evidence indicates that $K_{\text {ATP }}$ channels are partially responsible for the RVD process in rat cardiac myocytes (i.e. $\mathrm{K}_{\mathrm{ATP}}$ channels are regulated by cell volume changes). These findings are potentially important because the Kir6.1/Kir6.2-encoded $\mathrm{K}_{\mathrm{ATP}}$ plays a crucial part in protecting against ischemia and reperfusion in the heart. It may provide an alternative mechanism to the molecular linkage between ischemia cell death and volume regulation.

The mechanism underlying the activation of $\mathrm{K}_{\text {ATP }}$ channel by cell swelling remains unknown. Future studies will focus on signal pathways by which swelling activates the $\mathrm{K}_{\mathrm{ATP}}$ channels, and the possible contribution such changes in membrane conductance to ischemia- and reperfusion-induced injury.

\section{Conflict of Interest}

There is no conflict of interest.

\section{Acknowledgements}

This work was supported by National Natural Science Foundation of China (30670765) and Natural Science Foundation of Beijing (7072010).

\section{References}

CLEMO HF, STAMBLER BS, BAUMGARTEN CM: Swelling-activated chloride current is persistently activated in ventricular myocytes from dogs with tachycardia-induced congestive heart failure. Circ Res 84: 157-165, 1999.

DIAZ RJ, ARMSTRONG SC, BATTHISH M, BACKX PH, GANOTE CE, WILSON GJ: Enhanced cell volume regulation: a key protective mechanism of ischemic preconditioning in rabbit ventricular myocytes. $J \mathrm{Mol} C e l l$ Cardiol 35: 45-58, 2003.

DREWNOWSKA K, BAUMGARTEN CM: Regulation of cellular volume in rabbit ventricular myocytes: bumetanide, chlorothiazide, and ouabain. Am J Physiol 260: C122-C131, 1991.

HALL SK, ZHANG J, LIEBERMAN M: An early transient current is associated with hyposmotic swelling and volume regulation in embryonic chick cardiac myocytes. Exp Physiol 82: 43-54, 1997.

HOFFMANN EK, DUNHAM PB: Membrane mechanisms and intracellular signaling in cell volume regulation. Int Rev Cytol 161: 173-262, 1995. 
JENNINGS RB, SCHAPER J, HILL ML, STEENBERGEN C, REIMER KA: Effect of reperfusion late in the phase of reversible ischemic injury. Changes in cell volume, electrolytes, metabolites, and ultrastructure. Circ Res 56: 262-278, 1985.

KOCIC I, HIRANO Y, PETRUSEWICZ J, HIRAOKA M: Hypotonic stress enhances slope conductivity of ATPsensitive $\mathrm{K}^{+}$channels activated pharmacologically. Int J Cardiol 116: 423-424, 2007.

LANG F, BUSCH GL, RITTER M, VOLKL H, WALDEGGER S, GULBINS E, HAUSSINGER D: Functional significance of cell volume regulatory mechanisms. Physiol Rev 78: 247-306, 1998.

OKADA Y, MAENO E, SHIMIZU T, DEZAKI K, WANG J, MORISHIMA S. Receptor-mediated control of regulatory volume decrease (RVD) and apoptotic volume decrease (AVD). J Physiol Lond 532: 3-16, 2001.

PRIEBE L, BEUCKELMANN DJ: Cell swelling causes the action potential duration to shorten in guinea-pig ventricular myocytes by activating $\mathrm{I}_{\mathrm{KATP}}$. Pflugers Arch 436: 894-898, 1998.

REES SA, VANDENBERG JI, WRIGHT AR, YOSHIDA A, POWELL T: Cell swelling has differential effects on the rapid and slow components of delayed rectifier potassium current in guinea pig cardiac myocytes. $J$ Gen Physiol 106: 1151-1170, 1995.

SASAKI N, MITSUIYE T, WANG Z, NOMA A: Increase of the delayed rectifier $\mathrm{K}^{+}$and $\mathrm{Na}^{+}-\mathrm{K}^{+}$pump currents by hypotonic solutions in guinea pig cardiac myocytes. Circ Res 75: 887-895, 1994.

TRANUM-JENSEN J, JANSE MJ, FIOLET WT, KRIEGER WJ, DALNONCOURT CN, DURRER D: Tissue osmolality, cell swelling, and reperfusion in acute regional myocardial ischemia in the isolated porcine heart. Circ Res 49: 364-381, 1981.

VAN WAGONER DR: Mechanosensitive gating of atrial ATP-sensitive potassium channels. Circ Res 72: 973-983, 1993.

VANDENBERG JI, REES SA, WRIGHT AR, POWELL T: Cell swelling and ion transport pathways in cardiac myocytes. Cardiovasc Res 32: 85-97, 1996.

WANG GL, WAND GX, YAMAMOTO S, YE L, BAXTER H, HUME JR, DUAN D: Molecular mechanisms of regulation of fast-inactivating voltage-dependent transient outward $\mathrm{K}^{+}$current in mouse heart by cell volume changes. J Physiol Lond 568: 423-443, 2005.

WANG J, MORISHIMA S, OKADA Y: IK channels are involved in the regulatory volume decrease in human epithelial cells. Am J Physiol 284: C77-C84, 2003.

WANG J, XU H, MORISHIMA S, TANABE S, JISHAGE K, UCHIDA S, SASAKI S. OKADA Y: Single-channel properties of volume-sensitive $\mathrm{Cl}^{-}$channel in ClC-3-deficient cardiomyocytes. Jpn J Physiol 55: 379-383, 2005.

WANG J, XU H, SUN X, NIU W: Pharmacological and biophysical properties of swelling-activated chloride channel in mouse cardiac myocytes. Chin J Physiol 49: 126-131, 2006.

WEHER F, OLSEN H, TINEL H, KINNE-SAFFRAN E, KINNE RK: Cell volume regulation: osmolytes, osmolyte transport, and signal transduction. Rev Physiol Biochem Pharmacol 148: 1-80, 2003.

WU SN, WU AZ, SUNG RJ: Identification of two types of ATP-sensitive $\mathrm{K}^{+}$channels in rat ventricular myocytes. Life Sci 80: 378-387, 2007. 